\title{
The good, the bad and the ugly: Three faces of social media usage by local governments
}

\author{
Patrícia Silva $^{\mathrm{a}, *}$, António F. Tavares ${ }^{\mathrm{b}, \mathrm{c}}$, Tiago Silva ${ }^{\mathrm{f}}$, Mariana Lameiras ${ }^{\mathrm{d}, \mathrm{e}}$ \\ ${ }^{1}$ Research Unit in Governance, Competitiveness and Public Policies (GOVCOPP), Department of Social, Political and Territorial Sciences, University of Aveiro, $3810-193$ \\ Aveiro, Portugal \\ ${ }^{\mathrm{b}}$ Operating Unit on Policy-Driven Electronic Governance United Nations University (UNU-EGOV), Political Science Research Center, Campus de Couros, Rua Vila Flor 166, \\ 4810-445 Guimarães, Portugal \\ ${ }^{\mathrm{c}}$ Political Science Research Center, School of Economics and Management, University of Minho, Campus de Gualtar, 4710 - 057 Braga, Portugal \\ ${ }^{\mathrm{d}}$ United Nations University Operating Unit on Policy-Driven Electronic Governance (UNU-EGOV); Communication \& Society Research Centre (CSRC), University of \\ Minho, Campus de Couros, Rua Vila Flor 166, 4810-445 Guimarães, Portugal \\ ${ }^{\mathrm{e}}$ University of Minho, Campus de Gualtar, 4710 - 057 Braga, Portugal \\ ${ }^{\mathrm{f}}$ Social Science Institute, University of Lisbon (ICS-UL), Av. Professor Aníbal de Bettencourt, 9, 1600-189 Lisbon, Portugal
}

\section{A B S T R A C T}

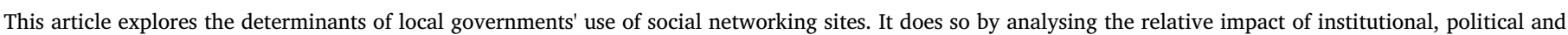

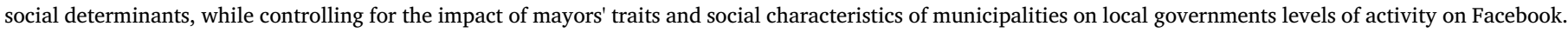

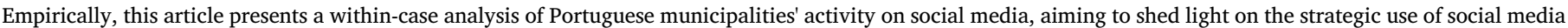

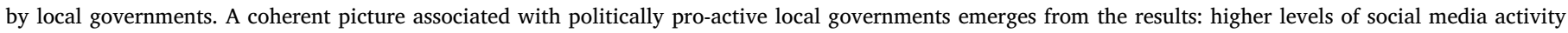

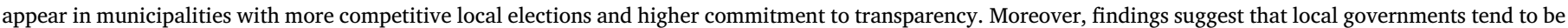

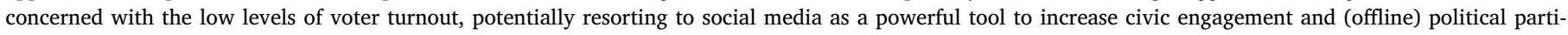

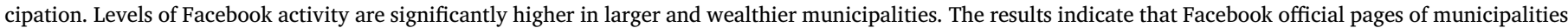
are part of a larger arsenal of tools to promote political engagement and activity levels signal a propensity to involve citizens pro-actively.

\section{Introduction}

A trend of democratic distrust has been asserted for decades, with tense and brittle relationships between citizens and governments (Foster \& Frieden, 2017). One of the main arguments for the increasing institutional distrust stems from the perception that political institutions are "unresponsive to citizens' demands" (Torcal, 2014, p. 1543), generating a widespread perception that citizens have lost faith in the performance of the core institutions of representative government.

One way to close the gap between citizens and politicians pertains to the use of new forms of interaction with citizens, particularly at the local level where greater proximity between citizens and local politicians tends to be associated with greater responsiveness. Social networking sites (SNS) are increasingly seen as the 'big idea' to enhance and restore public trust and confidence in institutions (Warren, Sulaiman, \& Jaafar, 2014); to foster open and accountable government (Song \& Lee, 2016); to galvanize deliberative and participatory democracy (Althaus \& Tewksbury, 2000); and to promote citizen engagement (Bonsón, Royo, \& Ratkai, 2015).

Notwithstanding the burgeoning research on e-government and, specifically, on the effects of social media on government-to-citizen relationships, extant research has scarcely dealt with the activity of local governments on social media - despite few notable exceptions (Bonsón, Torres, Royo, \& Flores, 2012; Larsson \& Skogerbø, 2018; Mossberger, Wu, \& Crawford, 2013; Reddick \& Norris, 2013). Their scope, however, is limited to the analysis of (politicians) perceptions (Hanssen, 2007; Larsson \& Skogerbø, 2018; Omar, Stockdale, \& Scheepers, 2014), deals with a multitude of online platforms, biased towards the largest and most innovative cities (Bonsón et al., 2012; Bonsón, Royo, \& Ratkai, 2017; Hofmann, Beverungen, Räckers, \& Becker, 2013; Mossberger et al., 2013), or estimates citizens' commitment to local governments' online interactive platforms (Haro-deRosario, Sáez-Martín, \& Caba-Pérez, 2018).

This article seeks to contribute to this discussion by adding an evidence-based dimension to the debates on the determinants of SNS usage by local governments. It seeks to do so by using a within-case

* Corresponding author at: Research Unit in Governance, Competitiveness and Public Policies (GOVCOPP), Department of Social, Political and Territorial Sciences, University of Aveiro, 3810-193 Aveiro, Portugal.

E-mail addresses: patriciasilva@ua.pt (P. Silva), atavares@eeg.uminho.pt, tavares@unu.edu (A.F. Tavares), tiago.silva@ics.ulisboa.pt (T. Silva), lameiras@unu.edu (M. Lameiras). 
design and moving beyond possible selection bias and ensuring (internal) validity by holding constant the levels of trust and the administrative tradition, which can impact on the predisposition to disclosure information and engage in e-participatory tools (Bonsón et al., 2015). Two interrelated objectives are targeted in this research. Beyond mapping the use of SNS Portuguese local governments, this article seeks to identify the determinants local governments' use of social networking sites, emphasizing the political incentives influencing different activity levels, while accounting for other institutional and sociodemographic factors.

Empirically, this research draws on a unique dataset of institutional Facebook pages of Portuguese municipalities. While local governments tend to elicit more trust from citizens, vis-à-vis other national and supranational institutions, Portugal depicts comparatively lower trust levels within the European context (Muñoz, 2017).

The remainder of this article is structured as follows. The following section discusses extant literature on the benefits and challenges of SNS use by the public sector and local government. Section three presents the main hypothesis derived from the theoretical framework. This is followed by the research design, presenting the research question, data collection, and the operationalization of variables. Section five presents the main results and section six discusses these findings. The article ends with a summary of the research findings, theoretical and practical implications, and future research agenda.

\section{A new communication tool for local government}

It is increasingly clear that local governments face unprecedented governance challenges. In contrast to other government levels, local governments need to act and interact with citizens that share the same territorial space (Omar et al., 2014). This privileged positioning is not without its shortcomings, as local governments struggle with limited financial resources, increased citizens' expectations and greater public scrutiny (Ellison \& Hardey, 2014). Rapid technological changes also ushered a new era for local governments. Whereas social media - herein defined as the digital space that facilitates the "diffusion of compelling content, dialogue creation, and communication to a broader audience (Kapoor et al., 2018: 536) - allow local governments to circumvent their limited resources, they have also pushed local governments to build larger networks with citizens, where both parties are actively engaged, instead of being passive bystanders (Bonsón et al., 2012, p. 131).

SNS - on par with other e-government strategies - are estimated to improve government-to-citizens' relationships, by creating a new venue for (low-cost) political activity in democratic policy making processes (Kahne \& Bowyer, 2018; Vaccari, 2017). The main rationale underlying this reasoning pertains to the availability of information, as a precondition to accessibility, transparency, public scrutiny, participation and accountability (Bonsón et al., 2012; Musso, Weare, \& Hale, 2000). By reducing information asymmetries and allowing citizens to monitor government activities (Katz \& Halpern, 2013), SNS can foster trustbased relationships (Warren et al., 2014), reduce corruption and promote accountability of public officials (Bertot, Jaeger, \& Grimes, 2010), and restore confidence in local government. Extant research has also highlighted the impact of social media on the success of electoral campaigns, by facilitating "voter engagement, public scrutiny, public harassment and polariz[ing] voting outcome" (Grover, Kar, Dwivedi, \& Janssen, 2018: 18).

The argument that SNS are a powerful tool to communicate with citizens has been questioned on a variety of grounds. Research has demonstrated that SNS have mainly contributed to local governments' mediatisation (Djerf-Pierre \& Pierre, 2016), as mechanisms used to accentuate the "status quo rather than to encourage participation" (Omar et al., 2014), as they create a perception of active political engagement, generating a tendency for apathy and lack of (offline) participation.
While there is an ongoing debate on the effect of e-government strategies on citizens' relationships with governmental institutions (vide, inter alia, Aladwani \& Dwivedi, 2018), more consensus seems to exist regarding the use of such tools as an asset for politicians. Hanssen (2007) argues that such tools allow politicians to improve communication between different local stakeholders and rapidly gather information on their preferences, which can be channeled into local policy-making. Moreover, local politicians are both vote- and officeseeking, lured by the advantages that incumbency promotes. SNS can be strategically used by politicians - particularly incumbents - by expanding the arenas where politicians can interact with voters (Enli \& Skogerbø, 2013).

Despite the vivid debates on the effects of SNS usage, research has yet to provide a comprehensive assessment of the motivations of local governments to use online platforms. A thread of research places the emphasis on organizational dimension by highlighting the impact of internal dynamics and institutional arrangements of governmental organizations (Mergel, 2016). Others have highlighted leadership capabilities of elected and/or appointed executives (Lee \& Kwak, 2012), or have focused on grassroots demands for e-participation (Reddick \& Norris, 2013). Finally, socio-demographic characteristics of the local population have been rarely put aside (Kavanaugh et al., 2012).

Given this somewhat scattered assessment of the determinants of SNS usage, our research aims at bridging three visible gaps in the literature. First, while a burgeoning literature has explored the determinants of the adoption of e-government in a comprehensive manner since the first decade of the 21st century (Moon \& Norris, 2005; Gallego-Álvarez, Rodríguez-Domínguez, \& García-Sánchez, 2010; Wang \& Feeney, 2016), it remains unclear whether the same factors which affect e-government adoption also influence the adoption and usage levels of SNS. Second, several studies have investigated how SNS contribute to citizen engagement in political and participatory activities (Kleinhans, Van Ham, \& Evans-Cowley, 2015; Haro-de-Rosario et al., 2018), but few question what drives local governments to use their official social media accounts in varying levels of intensity. Third, while there is a growing set of empirical studies exploring the determinants of social media usage by local governments (Guillamón, Ríos, Gesuele, \& Metallo, 2016; Martín, de Rosario, \& Pérez, 2015; Omar et al., 2014; Reddick \& Norris, 2013), this literature has yet to address the political incentives facing local government officials to adopt and extensively use SNS. Indeed, the impacts of local governments' strategic options are strongly dependent upon local actors' motivations. This is all the more relevant at the local level. Existing empirical research has been mainly focused on the national level - again, disregarding the specificities of local government politics, as suggested by Larsson and Skogerb $\varnothing$ (2018).

In order to provide a comprehensive understanding of the determinants of the activity of local governments on SNS, the following section articulates the institutional, political, and social incentives faced by local government officials when deciding the usage levels of SNS and presents the hypotheses derived from existing literature.

\section{Hypotheses}

This article aims to empirically assess the determinants of social media usage by Portuguese local governments. To this end, two operational objectives can be identified. First, this article seeks to map the use of Facebook by Portuguese local governments. We focus on Facebook since this is by far the preferred SNS of Portuguese local governments. The second operational objective concerns the identification of the determinants of the activity of Portuguese city governments on SNS. The assessment of the determinants of local governments' activity on SNS is structured around institutional, political and social incentives, which allow us to derive three sets of hypotheses. Overall, the theoretical framework argues not only that local government officials "choose" specific levels of Facebook activity depending 
on institutional capacity and political incentives, but also contends that they adjust activity levels to the influence of the socio-demographic characteristics of the local community. We proceed with presenting the three sets of premises.

\subsection{Institutional incentives}

Institutional capacity assessed by the availability of economic and technological resources has been associated with e-government adoption (Gallego-Álvarez et al., 2010; Tolbert, Mossberger, \& McNeal, 2008), dialogic communication capacity (Martín et al., 2015), adoption of open government principles (Grimmelikhuijsen \& Feeney, 2016), and social media institutionalization (Mergel, 2016). Whereas it is relatively simple and costless to create social media accounts, the effective maintenance and monitoring of those accounts can be costly in terms of time and human resources. While the lack of institutional capacity proxied by technical and economic capacity (Moon \& Norris, 2005) has been equated as a barrier to local governments' use of e-government strategies (Norris \& Reddick, 2013; Omar et al., 2014), this knowledge needs to be reassessed given the cost effectiveness of SNS for communication purposes vis-à-vis other e-government strategies. Administrative capacity has been theoretically presented as a variable that potentially affects policy results and outcomes - particularly at the local level (Milio, 2007). As the adoption of e-government strategies is dependent on administrative capacity - estimated as the number of employees in an organization (Chalmers, 2014) - it is expected that it positively impacts on the use of SNS. This leads us to the following pair of hypotheses:

$\mathbf{H}_{1 \mathbf{a}}$. The economic capacity of municipalities has a positive effect on local government activity on Facebook.

$\mathbf{H}_{\mathbf{1 b}}$. The administrative capacity of municipalities has a positive effect on local government activity on Facebook.

SNS are powerful tools for enhancing transparency and decreasing information asymmetries between local governments and citizens (Bonsón et al., 2012). The use of SNS to disclose the policy process to the public is, however, expected to depend on local governments' commitments towards transparency and accountability (Bertot et al., 2010). Higher levels of transparency suggest that local governments tend to be less apprehensive about making information "visible" and "accessible" (Song \& Lee, 2016), generating a greater tendency to adopt and use SNS. The following hypothesis can, thus, be advanced:

$\mathbf{H}_{\mathbf{1 c}}$. Local government activity on social media is positively affected by their level of commitment to transparency.

\subsection{Political incentives}

In contrast with institutional capacity factors, the role of political incentives in stimulating the use of SNS by local government remains underexplored in the literature. This omission is unfortunate, given local officials' commitment to re-election and the potential use of official social media accounts to further this goal. SNS can help increase the visibility of newly elected officials, promote local government policies in politically competitive environments, and stimulate political engagement of apathetic voters.

Political rivalry can create a favourable environment for technological reforms (Gallego-Álvarez et al., 2010), as it is estimated that political competition ensures the necessary vertical and horizontal accountability. Local government officials experiencing higher political competition have an incentive to rely more extensively on SNS to communicate their activities and decisions to citizens, local interest groups, and other stakeholders. Accordingly, research has identified a positive association between political competition and the disclosure of information on the municipalities' web sites (Ahn, 2011; García \&
García-García, 2010; Tavares \& da Cruz, 2017). Hence, we hypothesized that:

$\mathbf{H}_{2 \mathbf{a}}$. Higher electoral competition in local elections is associated with greater local government activity on social media.

Partisan (or mayor) alternation in local government may also impact on the willingness to disclose information through SNS. Normative debates tend to argue that alternation can have a positive role in bridging government's decisions to the citizens' preferences, therefore increasing a fundamental feature of democratic quality: the responsiveness of incumbents. Empirically, enduring and consecutive executive terms in office have been found to be negatively associated to the disclosure of information by local governments (Tavares \& da Cruz, 2017). This is particularly relevant in the Portuguese case where the electoral law for mayoral elections forces open-seat elections when mayors have served three consecutive terms. As such, new mayors will have an impetus towards greater activity on Facebook:

$\mathbf{H}_{\mathbf{2 b}}$. Mayoral alternation in local government (due to forced openseats) generates greater activity on social media.

The political spectrum may also impact on SNS usage by local governments. Although the ideological divide between political parties is becoming increasingly blurred, research has reported left-leaning politicians and political parties as being more internet-savvy. Left-wing political parties are more likely to disclose financial information and to report better transparency levels (Guillamón et al., 2016; López, Martínez, \& Oliva, 2011). López et al. (2011) suggest that progressive parties are more committed to releasing the municipalities' financial information in order to justify a larger public sector. There are, however, a number of studies that did not find any significant association between political ideology and the development of e-government (Domínguez, Nchez, \& Álvarez, 2011), the use of SNS for dialogic communication (Martín et al., 2015), the municipalities' levels of online transparency (Tavares \& da Cruz, 2017) and Facebook use (Guillamón et al., 2016). Considering that the two main purposes of the use of SNS by the public sector are a) to inform citizens and b) to promote e-participation, and since left-wing parties seem to be more likely to pursue these two objectives, we can expect that the SNS activity will be greater in municipalities ruled by left-wing parties. This leads to the following hypothesis:

$\mathbf{H}_{2 \mathbf{c}}$. Municipalities led by left-wing parties are more active on social media.

Political participation is a fundamental cornerstone of a well-functioning democracy (Lilleker \& Koc-Michalska, 2017). As SNS increase exposure to political content, it has been assumed as a predictor of online and offline participation, especially if it entails direct communication with (local government) organizations (Lilleker \& KocMichalska, 2017). Research has posited that (online) citizens' mobilization has greater potential to increase levels of political participation in scenarios where citizens are not already highly engaged (Vaccari, 2017). While prior research has found higher turnout to be associated with a higher demand for e-communication applications (Ahn, 2011), from the perspective of local government officials it is more likely that lower levels of turnout will trigger more activity on SNS. They may wish to counter political apathy evidenced by lower turnout by employing SNS to increase citizen engagement in politics. If local governments are concerned with civic engagement and citizens' trust towards government institutions, then they will resort to available and cost effective mechanisms to encourage citizen interest and participation at the local level. Hence, it can be argued that in scenarios where (civic and electoral) participation is low, local governments are pushed towards greater activity in SNS. As such, we can hypothesise that:

$\mathbf{H}_{2 \mathbf{d}}$. Lower levels of turnout increase local government's activity on social media. 


\subsection{Social incentives}

The size and socioeconomic status of local communities is likely to influence the adoption and usage levels of local governments' official SNS. Moon and Norris (2005) argue that larger city governments are more prone to engage in e-government activities. Larger municipalities feel more pressured to disclose information, and tend to have more resources at their disposal to respond to those demands. Hence, it can be expected that the use of SNS for institutional communication and eparticipation purposes is influenced by the size of the municipal population. The following hypothesis can be derived:

$\mathbf{H}_{3 \mathbf{a}}$. The activity of local governments on social media is positively influenced by the size of the municipal population.

In parallel, online interaction with governments tends to be more common amongst citizens with higher incomes (Reddick, 2005), with wealth emerging as a factor that also positively explains the use of SNS (Duggan \& Brenner, 2013). Hence, it can be expected that the level of purchase power to be positively associated with the intensity of SNS activity of local governments. The final hypothesis can, therefore, be derived:

$\mathbf{H}_{3 \mathbf{b}}$. The purchase power of the municipal population positively influences social media activity of local governments.

The following section details the data and methods used to test these three sets of hypotheses. It also presents the operationalization and descriptive analysis of variables.

\section{Data and methods}

Empirically, this article draws on social media data from Portuguese municipalities with a Facebook account. While several SNS platforms could be analysed, research has demonstrated that local politicians' preferential means of "preaching to the converted" (Norris, 2003) is Facebook (Larsson \& Skogerbø, 2018). Beyond its pervasiveness, Facebook is reported to present the clearest possibilities for a sustained interaction between citizens and local governments, given its cost-effectiveness and easiness (Ellison \& Hardey, 2013; Shiau, Dwivedi, \& Lai, 2018).

This research presents a within-case analysis, reporting the use of Facebook by Portuguese municipalities. Portugal can be a relevant case for comparative research. Although local government competences have gradually increased over the past forty years, their financial means are not extensive, and Portuguese local authorities remain tightly under the radar of the national government. Their fragility - at least compared to most of its European counterparts (De Ceuninck, Reynaert, Steyvers, \& Valcke, 2010, p. 807) - contrasts with higher levels of citizens' trust vis-à-vis central governmental institutions. Notwithstanding, trust in local and regional authorities is, yet again, lower, than in other European countries. According to the Eurobarometer, in November 2016, $41 \%$ of portuguese citizens claimed to trust local and regional autorities, a figure below the European average (47\%).

This within-case design also allows us to hold constant the institutional characteristics that can determine activity levels of local governments on SNS. The first pertains to the presidentialisation of local politics. Although citizens are expected to elect a collegial executive body composed of a Mayor and several councillors (depending on the size of the municipalities), Mayors have gained increasing relevance and power vis-à-vis other elected members. The use of the first-past-thepost plurality for the election of the mayor and closed-list proportional representation for the election of the municipal councillors, along with the Mayors' wide ranging set of powers have greatly contributed to the presidentialisation of the executive at the local level (Jalali, 2014, p. 239). Second, Portugal is embedded in a Southern European administrative culture - laggard in transparency and citizen engagement (Bonsón et al., 2015). This could prevent Portugal from exploiting the perks of a digital world. In contrast, the size of municipalities is considerably higher than the scenario found across OECD countries (OECD, 2008, p. 108), combined with narrow functions and municipal spending, which are theoretically expected to pull municipalities towards SNS.

All Facebook posts made by Portuguese municipalities during a three-month period in 2016 (September, October and November) were automatically collected using a package developed for $\mathrm{R} .{ }^{1}$ This package automatically retrieves the text message of each post; information about the type of post (i.e. if it includes an image, video, link, etc.) and its number of likes, comments, and shares. These data were complemented with information about the number of fans of each Facebook account and the creation date of those accounts. A total of 55,781 posts were collected from 290 municipalities. One outlier (Chamusca), which had a considerably higher post rate compared to all the other municipalities, and three municipalities that had Facebook accounts without a single post were excluded from the analyses. These data were supplemented with economic and socio-demographic data retrieved from the Portuguese Census Bureau (Instituto Nacional de Estatística). The following section outlines the results of this research, shedding light on how institutional, political and social factors influence the use of SNS by Portuguese local governments.

\section{Empirical results}

\subsection{Descriptive statistics}

This section starts out by presenting our findings through descriptive statistics. The vast majority of the Portuguese municipalities has already adopted Facebook, which is close to reaching its saturation point amongst local governments (Table 1), as only 14 out of the 308 municipalities are absent from Facebook. This SNS platform has been actively used in Portugal since 2009, with a considerable increase from 2010 to 2014.

While most Portuguese municipalities have a Facebook account, their activity is relatively low. On average, the Portuguese local governments made roughly two posts per day. There were, however, as we can see in Table 2, some municipalities that made an extensive use of Facebook to communicate with their citizens. From the 289 municipalities analysed, it was Alpiarça, a municipality of relatively small size (7389 residents), that more frequently conveyed information through Facebook (10.13 posts per day).

In order to estimate the levels of interaction with citizens, Table 2 also depicts Bonsón and Ratkai's (2013) set of measurements to assess citizen engagement through the indicators of popularity, commitment and virality - and municipalities activities on Facebook.

As to citizens' activities, data suggests that visitors of the municipalities' Facebook pages were much more likely to engage in terms of "likes" and/or "shares" than to comment on the posts. The least common form of engagement in social media was making a comment (commitment). There were several cases of municipalities with very few comments on their Facebook posts (two of them did not have a single comment in any of the posts). In fact, on average, the number of comments in the posts of Portuguese municipalities during the period under study is negligible (0.10).

Medium and large sized municipalities tend to be more active on Facebook, with population size being positively and significantly correlated with the activity of local governments $(r=0.566 ; p=.000)$. Notice, however, that the most active municipality is actually a small sized one, which cautions against the use of population size as case selection criteria in the study of SNS. Additionally, it is amongst the smallest municipalities that interaction with citizens and engagement

\footnotetext{
${ }^{1}$ Barbera, P., and M. Piccirilli. "Rfacebook: Access to Facebook API via R". R package version 0.3 (2014).
} 
Table 1

Presence of Portuguese local governments on Facebook (2009-2016).

\begin{tabular}{lll}
\hline Facebook page creation (year) & Municipalities (number) & $\%$ \\
\hline 2009 & 4 & 1.4 \\
2010 & 45 & 15.6 \\
2011 & 84 & 29.1 \\
2012 & 35 & 12.1 \\
2013 & 54 & 18.7 \\
2014 & 42 & 14.5 \\
2015 & 19 & 6.6 \\
2016 & 3 & 1.0
\end{tabular}

contrary to what we expected (H2b) mayoral alternation in local government (due to forced open-seat) does not seem to generate greater activity on SNS. It should be noticed, however, that levels of citizen engagement tend to be significantly higher in those cases where a new political party/ mayor runs office, as his predecessor was no longer eligible to run in the 2013 election, than in those cases with political continuity.

Differences between male and female mayors are not statistically significant, both in terms of Facebook activity and citizen engagement. However, as predicted, the mayors' education seems to be positively associated with higher levels of activity, with mayors with at least a

Table 2

Activities of municipalities and citizen engagement.

\begin{tabular}{|c|c|c|c|c|c|c|c|c|c|}
\hline \multicolumn{2}{|c|}{ Municipalities' activities } & \multicolumn{8}{|l|}{ Citizen activities } \\
\hline Posts (per day) & & Popularity $^{\mathrm{a}}$ & & Commitment $^{\mathrm{b}}$ & & Virality $^{\mathrm{c}}$ & & Engagement $^{\mathrm{d}}$ & \\
\hline Alpiarça [S] & $912(10.13)$ & Valpaços [S] & 17.87 & Seixal [S] & 0.73 & Valpaços [S] & 12.24 & Valpaços [S] & 30.45 \\
\hline Torres Vedras [M] & $797(8.86)$ & $\begin{array}{l}\text { Sobral de Monte Agraço } \\
\text { [S] }\end{array}$ & 15.91 & Penedono [S] & 0.73 & $\begin{array}{l}\text { Sobral de Monte Agraço } \\
\text { [S] }\end{array}$ & 12.09 & $\begin{array}{l}\text { Sobral de Monte Agraço } \\
\text { [S] }\end{array}$ & 28.30 \\
\hline Marinha Grande [M] & $779(8.66)$ & Tarouca [S] & 12.83 & Monforte [S] & 0.60 & Moura [S] & 9.09 & Mourão [S] & 18.23 \\
\hline Lisboa [L] & $728(8.09)$ & Calheta [S] & 12.68 & Calheta [S] & 0.53 & Sernancelhe $[\mathrm{S}]$ & 8.69 & Tarouca [S] & 17.73 \\
\hline Cascais [L] & $695(7.72)$ & Vila Nova de Poiares [S] & 12.32 & $\begin{array}{l}\text { Vila Nova de Poiares } \\
\text { [S] }\end{array}$ & 0.46 & Monchique [S] & 6.91 & Moura [S] & 17.52 \\
\hline Average & 187.83 (2.09) & & 3.67 & & 0.10 & & 1.45 & & 5.23 \\
\hline
\end{tabular}

Notes: in parenthesis, the size of the municipality $S=$ Small; $M=$ Medium; $L=$ Large.

a ((Total likes/total number of posts)/number of followers)*1000.

b ((Total comments/total number of posts)/number of followers)*1000.

c ((Total shares/total number of posts)/number of followers)*1000.

d Sum of popularity; commitment and virality.

tends to be higher, with population size being negatively correlated to all forms of citizen engagement: popularity $(r=-0.399 ; p=.000)$; commitment $(r=-0.225 ; p=.000) ;$ and virality $(r=-0.261$; $p=.000$ ). These results are consistent with existing research on the negative association of population size and (electoral and political) participation (Tavares \& Carr, 2013). The degree of interaction with citizens is relatively low, a pattern that does not deviate from other case studies (Mossberger et al., 2013).

Beyond size, other variables can impact on the levels of local government activity. Table 3 depicts levels of activity across different features related to political incentives and mayors' characteristics.

As depicted, the majority of local municipalities analysed were headed by parties/mayors from the left side of the political spectrum (i.e. Socialist Party, Communist Party or Left Bloc). As expected, these present relatively higher levels of Facebook activity, though the reported differences are not statistically significant. In the same vein,

Table 3

Municipalities' activities and citizens' engagement across political and individual features.

\begin{tabular}{|c|c|c|c|c|}
\hline & & $\mathrm{N}$ & $\begin{array}{l}\text { Facebook } \\
\text { activity (post } \\
\text { rate per day) }\end{array}$ & $\begin{array}{l}\text { Citizen's } \\
\text { engagement }\end{array}$ \\
\hline \multirow{2}{*}{$\begin{array}{l}\text { Ideological } \\
\text { positioning }\end{array}$} & $1=$ Left wing & 172 & 195.14 (1.97) & 5.07 \\
\hline & $0=$ Right wing & 117 & 177.09 (2.17) & 5.47 \\
\hline \multirow[t]{2}{*}{ Forced Open seat } & $1=$ Yes & 36 & $160.25(2.13)$ & $4.44 *$ \\
\hline & $0=$ No & 253 & $191.76(1.78)$ & 4.02 \\
\hline \multirow[t]{2}{*}{ Mayor's Gender } & $1=$ Female & 23 & $194.96(2.16)$ & 4.73 \\
\hline & $0=$ Male & 266 & $187.22(2.08)$ & 5.27 \\
\hline \multirow[t]{2}{*}{ Mayor's education } & $\begin{array}{l}1=\text { At least } \\
\text { Bachelor }\end{array}$ & 44 & $195.15^{*}$ & 5.14 \\
\hline & $0=$ Otherwise & 245 & 147.09 & 5.73 \\
\hline
\end{tabular}

Notes: differences are statistically different (Independent samples $t$-test), at the level $p<0.05$;

a Sum of popularity; commitment and virality (Bonsón \& Ratkai, 2013). bachelor's degree presenting significantly higher levels of SNS activity.

The descriptive statistics of all continuous variables included in the regression models are depicted in Table 4. Our dependent variable is the level of Facebook activity of Portuguese local governments, measured by the natural logarithm of the municipalities' post count in this SNS in the three-month period under analysis. Table 4 also presents the Pearson correlation coefficients between the independent variables and the level of Facebook activity. As depicted, the majority of predictors emerge as significantly correlated with the dependent variable, and in the expected direction.

The economic capacity of the local governments is measured by the percentage of the total revenues generated within the municipalities (e.g. local taxes and fees). On average, the percentage of the municipalities' own revenues is about $39 \%$. A Municipal Transparency Index (MTI), focused on the type and quantity of information disclosed in the municipalities' web pages (that does not take into account the use of SNS by local governments), is used to assess the level of commitment to transparency of the municipalities. ${ }^{2}$ The values in this variable range from 0.8 to 94, corresponding, respectively, to the least and most transparent municipalities.

Following Ahn (2011), margin of victory measures the difference, in percentage points, between the two most voted parties in the previous local election, that took place in September 2013. The smaller the value of this measure is, the more competitive the election was. Turnout in the 2013 local elections appears to be negatively associated with Facebook activity, whereas the mayors' age is not significantly correlated

\footnotetext{
${ }^{2}$ The Municipal Transparency Index is an addictive index, which considers 76 indicators on information that should be available on local government official websites. The list of indicators includes: organizational information, social composition, and operation of the municipality; plans and planning; local taxes, rates, service charges, and regulations; relationship with citizens as customers; public procurement; economic and financial transparency; urban planning and land use management (for a more detailed analysis of the index, see da Cruz et al., 2015).
} 
Table 4

Descriptive Statistics of the Variables and Pearson's $r$.

\begin{tabular}{|c|c|c|c|c|c|c|}
\hline Variables & Indicator & Mean & Std. Dev. & Min. & Max. & Pearson's $r$ \\
\hline \multicolumn{7}{|l|}{ Dependent variable } \\
\hline Facebook Activity & Natural log of Facebook posts count & 4.96 & 0.77 & 1.61 & 6.82 & - \\
\hline \multicolumn{7}{|l|}{ Institutional incentives } \\
\hline Economic capacity & Percentage of own revenues & 39.42 & 18.11 & 7.83 & 90.21 & $0.477^{* *}$ \\
\hline Administrative capacity & Number of effective employees & 74.94 & 37.22 & 15.58 & 198.25 & $0.310^{* *}$ \\
\hline Transparency & Municipal Transparency Index (da Cruz, Tavares, Marques, Jorge, \& de Sousa, 2016) & 44.56 & 17.22 & 0.82 & 94.23 & $0.274^{* *}$ \\
\hline \multicolumn{7}{|l|}{ Political incentives } \\
\hline Margin of Victory & Difference in percentage points between 1st and 2nd place parties (2013) & 19.43 & 14.13 & 0.03 & 75.85 & $-0.118^{*}$ \\
\hline Turnout & Turnout in the Election (2013) & 59.04 & 9.09 & 37.77 & 82.03 & $-0.399 * *$ \\
\hline \multicolumn{7}{|l|}{ Mayors' characteristics } \\
\hline Mayor's Age & Age of mayors in years & 51.75 & 8.26 & 32 & 74 & n.s. \\
\hline \multicolumn{7}{|l|}{ Social incentives } \\
\hline Purchase Power & Per capita purchasing power (2013) & 80.82 & 18.45 & 56.54 & 207.91 & $0.450 * *$ \\
\hline Population (log) & Natural log of Municipal Population & 9.73 & 1.13 & 7.28 & 13.21 & $0.566^{* *}$ \\
\hline SNS Interest & Number of Facebook Fans divided by Population & 0.61 & 0.52 & 0.02 & 3.39 & $-0.156^{*}$ \\
\hline
\end{tabular}

Notes: ** Correlation is significant at the $.001 ; *$ Correlation is significant at the .05 level.

with SNS activity. Both variables assessing social incentives show a positive association with the dependent variable: the size of the municipality (expressed as the natural $\log$ of the total number of residents in each municipality); and the wealth of the municipality (measured by the national statistics index on per capita purchasing power in each municipality ${ }^{3}$ ).

\subsection{Regression results}

This article seeks to assess the determinants of local governments' use of SNS. It does so by analysing the relative impacts of institutional, political, and social incentives. Considering the tendency for the presidentialisation of municipal executives, our model also assesses the effects of the mayors' characteristics. Extant research has posited that different political and socio-demographic backgrounds, as well as professional experience can explain e-government administrative tools at the local level (Larsson \& Skogerb $\varnothing, 2018$; Tavares \& Rodrigues, 2013). While experienced male politicians tend to depict higher "media capital" (Larsson \& Skogerbø, 2018, p. 4), female mayors are expected to bypass the traditional media bias by resorting to SNS to a higher extent. Female mayors are also associated with greater levels of transparency (Tavares \& da Cruz, 2017) and more prone towards encouraging citizen (or other external stakeholders) participation and involvement in decision-making (Carrizales, 2008; Fox \& Schuhmann, 2014). In addition, mayors with higher levels of formal education are more likely to display higher usage levels of SNS to communicate and interact with citizens, as it has been posited as a determinant of e-government initiatives at the local level (Carrizales, 2008). Likewise, it is likely that younger mayors have been more exposed to new information technologies and SNS, being also more capable of adapting to them than their older counterparts (Larsson \& Kalsnes, 2014).

All regression models control for citizens' interest on SNS, particularly their interest on the local governments' SNS accounts. This control variable is measured as the number of Facebook fans, divided by the size of municipalities. Indeed, if a relatively large number of fans is following a municipality's Facebook account, this municipality has an added incentive to communicate more regularly. The empirical assessment of the determinants of local governments' use of SNS is performed through ordinary least squares (OLS) analysis. As aforementioned, regression models were estimated using the dependent variable in its log-transformed state. This transformation was required to pull outlying data from a positively skewed distribution closer to the bulk of

\footnotetext{
${ }^{3}$ Statistics Portugal (2015). Study on the Local Purchasing Power (2013), available at https://www.ine.pt/ngt_server/attachfileu.jsp?look_parentBoui= 245204632\&att_display $=$ n\&att_download $=y$ (consultd in 15 march 2017).
}

the data. This procedure upholds the assumption of a normally distributed dependent variable.

We begin by examining how much of the variance in local government activity can be explained by institutional, political or social incentives. As the adjusted R-squared compares the explanatory power of regression models that contain different numbers of predictors, Fig. 1 plots the relative impact of each of the three sets of incentives estimated in the regression models.

The results of OLS regression models are presented in Table 5. As depicted, the $F$-value is statistically significant $(p<.05)$ across all models, suggesting a significant amount of variance in the outcome variable being explained by institutional, political, and social incentives. Overall, almost all the coefficients exhibit the expected signs as hypothesized, with their magnitude and standard errors showing consistency across the different models. The following section discusses the results of the full model, occasionally mentioning the partial models for relevant comparisons.

\section{Discussion of results: the determinants of Facebook usage by local governments}

As depicted, variance in the levels of Facebook activity is best explained by the social and demographic features of the community and, specifically, by the size of the population $\left(\mathrm{H}_{3 \mathrm{a}}\right)$ and purchase power $\left(\mathrm{H}_{3 \mathrm{~b}}\right)$. Without further control variables, the sociodemographic profile of the municipalities accounts for $37 \%$ of the variation in SNS usage, suggesting that local governments tend to interact more with citizens in larger and wealthier municipalities. This raises potential questions about the equality of access to information and the relationship of citizens with local governments across the country, with local governments seemingly contributing to the entrenchment of existing differences. However, consistent with existing research (Bonsón et al., 2017), when a full model is estimated, larger municipalities tend to be more active than smaller ones.

The municipalities' financial and administrative capacity and commitment to transparency also emerge as capable of explaining $27 \%$ of the variation in SNS activity. This particular set of results is aligned with existing research that tends to emphasize the institutions' organizational dimension and internal procedures as key factors in the pursuance of government strategies (Mergel, 2016).

When combined into a multivariate model, however, important differences emerge. Regarding the institutional variables, only the municipalities' commitment to transparency maintains a positive and significant effect, as predicted $\left(\mathrm{H}_{1 \mathrm{c}}\right)$. As depicted in the full model, a one-unit increase in the MTI score is associated with an increase of about $0.6 \%$ in Facebook activity. This means that a local government 


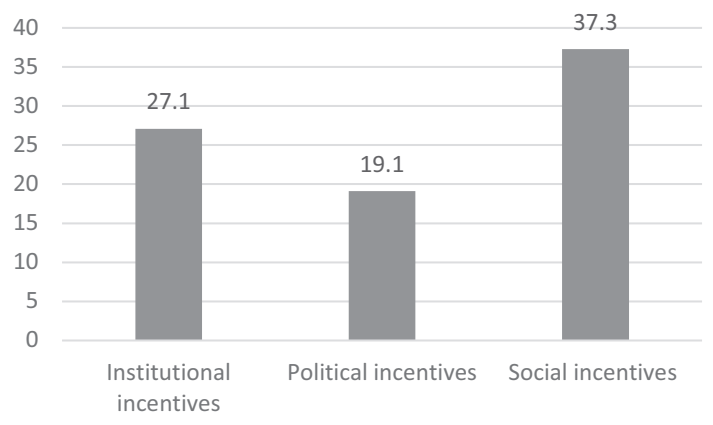

Fig. 1. Explained variance (Adjusted $R$-Square).

Table 5

OLS Estimations (Dependent Variable: Facebook Post Count (log)).

\begin{tabular}{|c|c|c|c|c|}
\hline Variables & Institutional & Political & Social & $\begin{array}{l}\text { Full Model } \\
\text { w/interaction }\end{array}$ \\
\hline \multicolumn{5}{|l|}{$\begin{array}{l}\text { Institutional } \\
\text { Incentives }\end{array}$} \\
\hline Economic capacity & $\begin{array}{l}0.0186_{\text {**** }} \\
(0.00249)\end{array}$ & & & $\begin{array}{l}-0.00192 \\
(0.00356)\end{array}$ \\
\hline $\begin{array}{l}\text { Administrative } \\
\text { capacity }\end{array}$ & $\begin{array}{l}0.00351_{* * *} \\
(0.00112)\end{array}$ & & & $\begin{array}{l}-0.00139 \\
(0.00141)\end{array}$ \\
\hline $\begin{array}{l}\text { Transparency } \\
\text { (MTI) }\end{array}$ & $\begin{array}{l}0.00768_{* * *} \\
(0.00224)\end{array}$ & & & $\begin{array}{l}0.00571_{\text {水水水 }} \\
(0.00202)\end{array}$ \\
\hline \multicolumn{5}{|l|}{ Political Incentives } \\
\hline Margin of victory & & $\begin{array}{l}-0.00989_{* * *} \\
(0.00300)\end{array}$ & & $\begin{array}{l}-0.0133_{* * *} \\
(0.00339)\end{array}$ \\
\hline Forced open seat & & $\begin{array}{l}-0.287 * * \\
(0.136)\end{array}$ & & $\begin{array}{l}-0.232_{\text {水 }} \\
(0.119)\end{array}$ \\
\hline Ideology (left) & & $\begin{array}{l}0.0913 \\
(0.0854)\end{array}$ & & $\begin{array}{l}-0.0850 \\
(0.116)\end{array}$ \\
\hline Turnout & & $\begin{array}{l}-0.0399_{\text {水水水 }} \\
(0.00520)\end{array}$ & & $\begin{array}{l}-0.00968_{*} \\
(0.00560)\end{array}$ \\
\hline $\begin{array}{l}\text { Ideology }_{*} \text { Margin } \\
\text { of Victory }\end{array}$ & & & & $\begin{array}{l}0.00991_{\text {** }} \\
(0.00502)\end{array}$ \\
\hline \multicolumn{5}{|l|}{ Social Incentives } \\
\hline $\begin{array}{l}\text { Population size } \\
\text { (log) }\end{array}$ & & & $\begin{array}{l}0.460_{\text {决* }} \\
(0.0531)\end{array}$ & $\begin{array}{l}0.457 \text { 栦* } \\
(0.0768)\end{array}$ \\
\hline Purchase Power & & & $\begin{array}{l}0.00520_{* *} \\
(0.00226)\end{array}$ & $\begin{array}{l}0.00421 \\
(0.00279)\end{array}$ \\
\hline \multicolumn{5}{|l|}{ Control Variables } \\
\hline SNS interest & $\begin{array}{l}0.205_{* * * *} \\
(0.0785)\end{array}$ & $\begin{array}{l}0.130 \\
(0.0871)\end{array}$ & $\begin{array}{l}0.413_{\text {**** }} \\
(0.0844)\end{array}$ & $\begin{array}{l}0.442_{\text {桃 }} \\
(0.0841)\end{array}$ \\
\hline Mayor's gender & $\begin{array}{l}0.151 \\
(0.117)\end{array}$ & $\begin{array}{l}0.134 \\
(0.114)\end{array}$ & $\begin{array}{l}0.190_{*} \\
(0.105)\end{array}$ & $\begin{array}{l}0.146 \\
(0.104)\end{array}$ \\
\hline Mayor's education & $\begin{array}{l}-0.0199 \\
(0.104)\end{array}$ & $\begin{array}{l}0.0448 \\
(0.108)\end{array}$ & $\begin{array}{l}-0.0992 \\
(0.0994)\end{array}$ & $\begin{array}{l}-0.143 \\
(0.0920)\end{array}$ \\
\hline Mayor's age & $\begin{array}{l}-0.00174 \\
(0.00500)\end{array}$ & $\begin{array}{l}-0.00425 \\
(0.00513)\end{array}$ & $\begin{array}{l}-0.00320 \\
(0.00472)\end{array}$ & $\begin{array}{l}-0.00805_{*} \\
(0.00465)\end{array}$ \\
\hline Constant & $\begin{array}{l}3.589 \text { **** } \\
(0.292)\end{array}$ & $\begin{array}{l}7.580_{* * *} \\
(0.489)\end{array}$ & $\begin{array}{l}0.0463 \\
(0.493)\end{array}$ & $\begin{array}{l}1.150 \\
(0.799)\end{array}$ \\
\hline Observations & 288 & 288 & 288 & 288 \\
\hline R-squared & 0.285 & 0.210 & 0.386 & 0.442 \\
\hline $\begin{array}{l}\text { Adjusted R- } \\
\text { squared }\end{array}$ & 0.267 & 0.188 & 0.373 & 0.414 \\
\hline F-test & 18.81 & 11.72 & 26.44 & 15.58 \\
\hline Prob $>F$ & 0 & 0 & 0 & 0 \\
\hline
\end{tabular}

Notes: Robust standard errors in parentheses;

*** $p<0.01$

** $\mathrm{p}<0.05$,

${ }^{*} p<0.1$.

fully committed to transparency (with an MTI score of 100) would have $60 \%$ more Facebook posts than a municipality with a zero score in this index.

Economic and administrative capacity fail to achieve statistical significance - against $\mathrm{H}_{1 \mathrm{a}}$ and $\mathrm{H}_{1 \mathrm{~b}}$. It is possible that the "distributed, accessible, and malleable nature of a SNS" requires fewer "raw resources", and instead depends on municipalities' innovative culture
(Oliveira \& Welch, 2013, p. 401). Local governments with substantial budgets and administrative capacity might prefer to build political support through other mechanisms. It also remains as a puzzle the extent to which these variables impact on the 'quality' and content of the Facebook messages, rather than on their quantity.

Unlike institutional variables, political determinants' results hold when combined in the full model and provide a novel set of findings. The use of SNS is directly affected by local political dynamics. Political competition has been extensively reported as having a virtuous effect on economic performance and higher levels of transparency. Regression estimates - both in the limited and the full model - suggest that higher levels of political competition (operationalized by lower margins of victory) generated a greater tendency for local governments to communicate with their constituencies through SNS. As such, in line with extant research (García \& García-García, 2010; Tavares \& da Cruz, 2017), results across models consistently suggest that in the absence of competition, accountability withers, confirming $\mathrm{H}_{2 \mathrm{a}}$.

But it is not simply a question of placing greater emphasis on government-to-citizens' relationship, particularly considering the low levels of citizen engagement aforementioned. As high political competition places additional constraints on local governments (potentially impacting on the odds of incumbents being re-elected) SNS might be used as a means to achieve re-election, more than as a strategy to increase participation and citizen engagement in the formulation of public policies. Beyond generating a greater tendency to inform citizens, the use of SNS to disclose information on the activities of local governments may also be used to feed local newspapers, potentially boosting the audience of local governments' activities.

Contrary to $\mathrm{H}_{2 \mathrm{~b}}$, forced open seats do not generate greater impetus towards higher levels of SNS activity. This result is, however, noteworthy. While political continuity (consecutive terms) in local executives has been reported as "detrimental to the adoption of information disclosure and open government principles" (Tavares \& da Cruz, 2017, p. 8), it emerges as a strong predictor of SNS usage - again suggesting that further analysis needs to be undertaken to assess the content of such activity.

The ideological positioning of local executives does not emerge as a significant predictor of levels of activity in SNS, diverging from $\mathrm{H}_{2 \mathrm{c}}$. The left-right divide is an irrelevant predictor, potentially due to the presidentialisation and a stronger focus on mayors' characteristics. Not all personal traits seem to impact on SNS activity, though. As depicted in the full model, age is the only individual level factor that determines the level of SNS activity. Younger mayors tend to be more exposed to online platforms such as the SNS, being also more prone to engage in SNS.

Ideology seems, however, to interact with political competition, as depicted in Model 6. Indeed, the ideology of the party in charge of the local government (being a left-wing party) appears to have a moderating effect on the impact of the margin of victory in the previous election on Facebook activity of the Portuguese municipalities. As we can see in Fig. 2, the effect of electoral competition on the municipalities' post count is higher when municipalities are ruled by rightwing governments. Contrarily, when a municipality is ruled by a leftwing party, the electoral competitiveness of the previous election does not appear to have any relationship with Facebook activity.

Furthermore, as depicted in Fig. 3, the differences between left and right-wing local governments increase when the margin of victory in the previous election increases, with the differences becoming statistically significant when the margin of victory is higher than 26 percentage points. In other words, when a mayor wins an election by a large margin, the municipality will be considerably less active on Facebook if that mayor belongs to a right-wing party.

Local governments also seem to use Facebook when turnout levels are lower. This is a peculiar result. Despite Dalton's (2002) seminal work arguing that politicians tend not to be concerned with poor turnout levels, our results suggest that - at least at the local level - low 


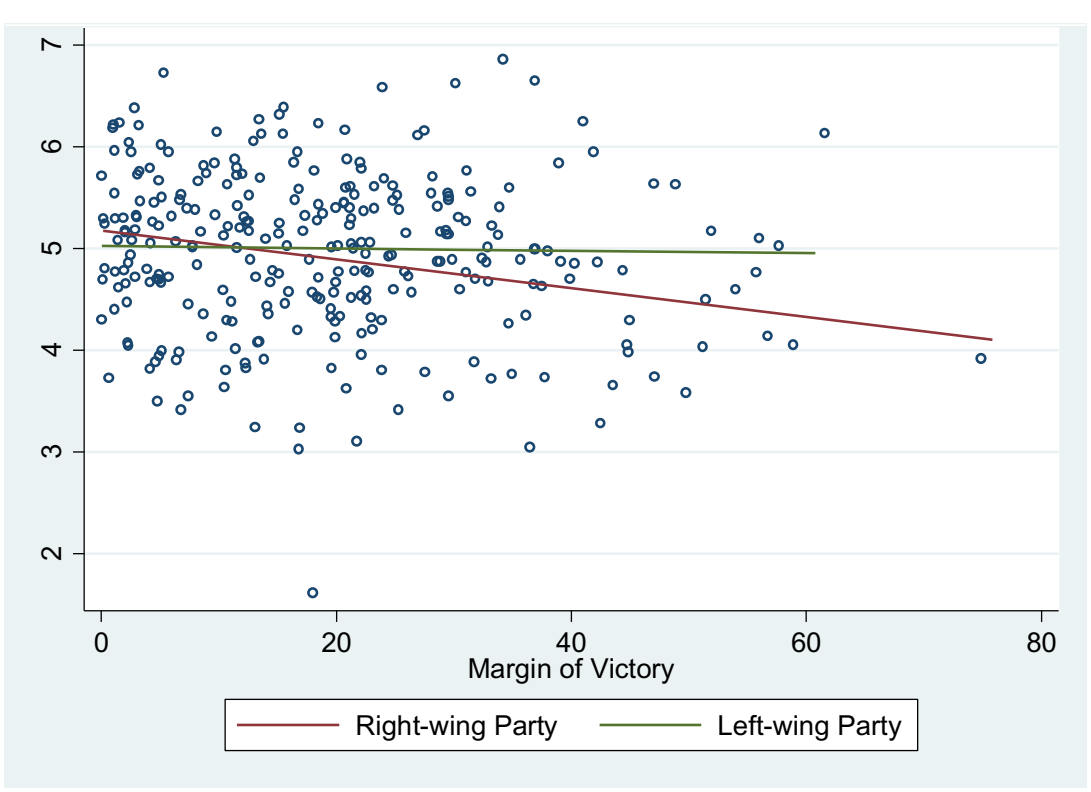

Fig. 2. Effect of political competition on post count (log) by political partisanship (left-right).

turnout tends to generate greater concerns about the levels of political participation, with SNS potentially emerging as a valuable tool of mobilization, as predicted $\left(\mathrm{H}_{2 \mathrm{~d}}\right)$. This result holds even when we control for the other institutional and social factors. In fact, the hypothesis of the negative impact of turnout on the levels of Facebook activity is confirmed if we take into account a less strict cut-off such as 0.10 .

Finally, it is worth noticing that regardless of the models estimated, citizen interest on the Facebook accounts of the local governments seems to encourage these municipalities to be more active on that SNS. Together with the results on social determinants, it can be argued that local governments seek to respond to citizen interest and demand for information and communication. Hence, a multivariate analysis unveils a very different pattern from the descriptive stance explored in existing research (Bonsón et al., 2017), while also suggesting the need to empirically look beyond larger sized local governments.

\subsection{Contributions to theory}

This article provides a more comprehensive explanation for the use of SNS by local governments. The contribution to the literature is threefold. First, while prior research has focused primarily on the institutional capacity and sociodemographic features of local communities as drivers of activity levels on local governments' official social media accounts, we contribute to this literature by highlighting the political incentives and elected officials' motivations for extensive reliance on Facebook. Our findings indicate that the use of official Facebook accounts by municipal governments aims to increase the visibility of newly elected officials, to advance local government policies in politically competitive environments, and to foster the political engagement of apathetic voters. While our analysis does not show the effective accomplishment of these goals, it does suggest that Facebook usage levels correspond to specific political incentives faced by local officials.

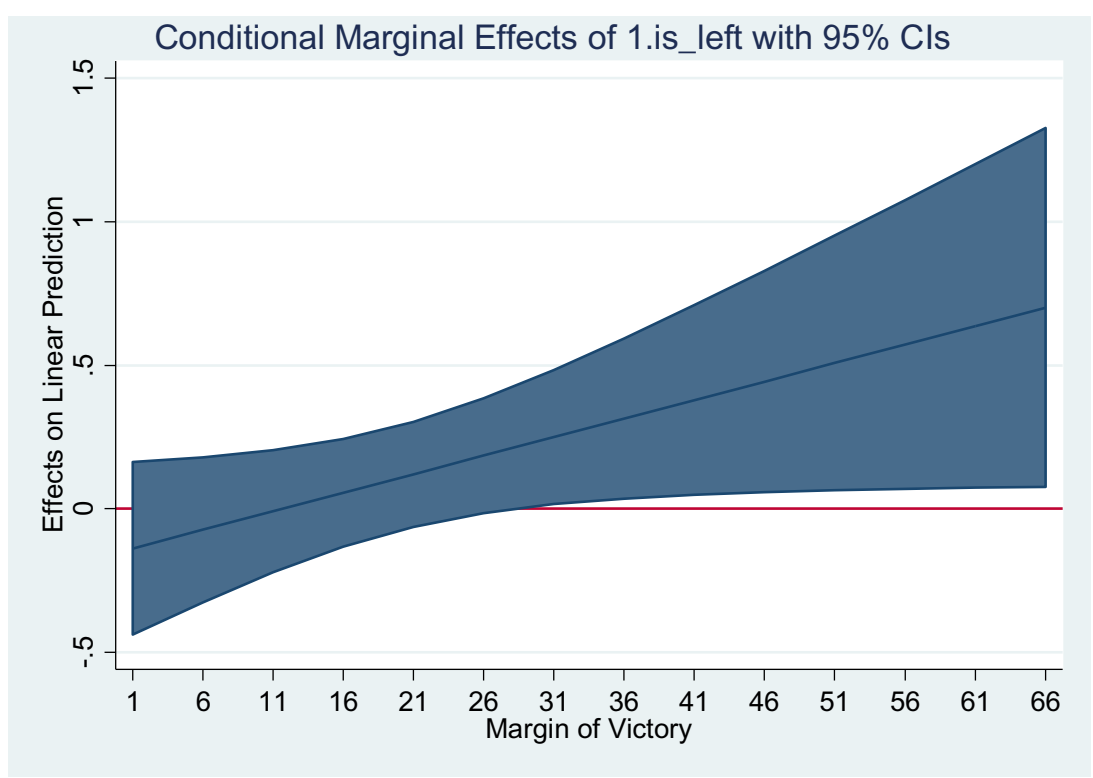

Fig. 3. Marginal effects of political partisanship on post count (log) conditional on margin of victory. 
Second, besides bridging this important lacuna concerning the role of political incentives, the analysis also underlines the association between municipalities' commitment to transparency and the use of SNS such as Facebook. This suggests that transparency can come in multiple formats and using different tools, not only promoted via official local government webpages, but also through more dialogic tools of communication between local governments and their citizens. This finding also highlights that, like transparency levels, different levels of activity on official Facebook pages also result from conscious choices by local government officials.

Lastly, this research underlines the link between online and offline forms of participation in a novel way. Local governments tend to rely more on Facebook in municipalities facing lower voter turnout levels. While the connection between turnout and social media usage is not entirely new, earlier findings have focused primarily on the idea that online and offline political engagement are positively associated from a citizen perspective. Our research extends these earlier works to suggest that local officials do not take a passive stance when facing lower turnout rates, but instead rely on SNS as tools to promote political engagement.

\subsection{Implications for policy and practice}

From the local officials' perspective, the advantage of using Facebook is the relatively costless access to a large audience of their constituencies. The benign interpretation of our results is that local government officials can use institutional accounts to enhance transparency and improve citizen engagement in public affairs. If employed with public goals in mind, official accounts can bridge the gap in institutional trust between governments and citizens and contribute to healthier democratic practices.

However, there is a negative side to the use of official Facebook accounts to promote private interests, particularly re-election goals. The analysis included in this article suggests that Facebook institutional accounts of municipalities are employed frequently having political goals in mind. This raises ethical issues concerning the separation of public and private interests. Monitoring, control and sanctions against this type of political opportunism are essential to ensure that official SNS are employed exclusively for institutional purposes rather than for the promotion of incumbents. That said, it is unlikely that the regulation of SNS becomes a successful (or even desirable) endeavour in the near future, so ultimately the task to separate legitimate and illegitimate uses of official SNS will be left to constituencies.

\section{Concluding remarks and implications: the good, the bad and the ugly sides of social media}

SNS brought a 'spring of hope' for local governments, to paraphrase the title of Dickens' well-known novel. Potentially emerging as an instrument to improve government-to-citizens' relationship, SNS have been extensively used by Portuguese local governments. This activity appears to emerge as a mechanism to reinforce other e-government strategies. Indeed, data reported on this article suggests that Facebook is still primarily used as a new communication tool to inform a wider audience in municipalities that perform better in terms of their commitment to transparency in municipal websites. This is done by resorting to a tool capable of reaching a broader public, particularly when compared to official websites. Results also indicate that even in contexts characterized by low levels of voter turnout, Portuguese local governments are concerned with lower offline political participation levels, potentially resorting to SNS as a powerful asset to increase civic engagement and online political participation, hoping to generate spillover effects on offline activities.

The 'bad' side of Facebook usage by local governments lies in the difficulties of meeting high expectations. Similar to existing research (Bonsón et al., 2012), our analysis suggests that Facebook, in the
Portuguese context, is mostly used by local governments to inform citizens rather than to promote later stages of e-participation (i.e. online deliberation and collaboration). Indeed, citizen engagement with the Facebook accounts of local governments is rather limited. Despite its accessibility, and the capacity to present information in a visually "pleasing and understandable format" (Musso et al., 2000, p. 3), Facebook has yet to become an effective tool for involving citizens in political decisions at the local level.

Finally, the use of SNS appears to be incapable of purging the 'ugly' side of local politics. Political incentives seem to play an enduring role as determinants of SNS activity. Political competition emerges as a push-factor towards SNS usage levels. When elections are won by comfortable margins, local governments are less prone to use SNS. The political motivations underlying the decision to use Facebook are, however, open to contention. On the one hand, winning elections by small margins of victory creates stronger opposition parties that can hold the executive under scrutiny, encouraging municipal executives to improve their communication strategies. On the other hand, the officeseeking nature of political parties cannot be disregarded. It is likely to generate higher activity levels with more opportunistic or electoral motivations behind it. It is possible that Facebook is being used merely as a tool of political propaganda and promotion of the local executive seeking re-election. This hypothesis deserves further investigation particularly considering that data was collected one year before the 2017 local elections. The fact that margins of victory seem to impact particularly on right-wing governments points in this direction. Indeed, in the 2013 local elections, the centre-left Socialist Party won the majority of municipalities, which might have steered municipalities led by right-wing governments to significantly invest in 'preaching' to their potential future electorate - taking advantages of the perks of being in office.

\subsection{Limitations and directions for future research}

These concluding remarks on the good, the bad and the ugly sides of SNS usage by local governments presented in this article point towards several avenues for future research. First, given the personalization of the internet - especially visible in SNS - future research should assess the individual usage of SNS. While mayors' personal traits do not seem to impact on the levels of local government activity on SNS, research has yet to equate the extent to which mayors are using personal accounts on Facebook to directly connect with their constituents. This assessment is particularly relevant given the personalization of politics at the local level. Additionally, whereas data suggests that local governments tend to be active on Facebook, extant research has not found much evidence that SNS have replaced traditional local media.

This article is also limited to the analysis of municipalities' frequency in social media usage, largely disregarding the content analysis of local government online communication and the extent it can reverse the waning trust of citizens in their regional or local public authorities. Future research should seek to test recent theoretical models (e.g. Aladwani \& Dwivedi, 2018). In particular, the extent to which unmediated citizens' interaction with local government institutions (vis-àvis traditional media) tend to generate higher levels of (institutional) trust.

\section{Acknowledgements}

This research received funding from the project "SmartEGOV: Harnessing EGOV for Smart Governance (Foundations, methods, Tools)/NORTE-01-0145-FEDER-000037", supported by Norte Portugal Regional Operational Programme (NORTE 2020), under the PORTUGAL 2020 Partnership Agreement, through the European Regional Development Fund (EFDR) and from the Portuguese Foundation for Science and Technology and the Portuguese Ministry of Education and Science through national funds [Grant No. UID/CPO/ 
0758/2019]. Any opinions, findings, and conclusions or recommendations expressed in this material are those of the authors. The authors would also like to thank the anonymous referees for their helpful and constructive comments that greatly contributed to improving the final version of the article.

\section{References}

Ahn, M. J. (2011). Adoption of e-communication applications in U.S. municipalities: The role of political environment, bureaucratic structure, and the nature of applications. The American Review of Public Administration, 41, 428-452.

Aladwani, A., \& Dwivedi, Y. (2018). Towards a theory of SocioCitizenry: Quality anticipation, trust configuration, and approved adaptation of governmental social media. International Journal of Information Management, 43, 261-272.

Althaus, S., \& Tewksbury, D. (2000). Patterns of internet and traditional news media use in a networked community. Political Communication, 17(1), 21-45.

Bertot, J., Jaeger, P., \& Grimes, J. (2010). Using ICTs to create a culture of transparency: E-government and social media as openness and anti-corruption tools for societies. Government Information Quarterly, 27(3), 264-271.

Bonsón, E., \& Ratkai, M. (2013). A set of metrics to assess stakeholder engagement and social legitimacy on a corporate Facebook page. Online Information Review, 37(5), 787-803.

Bonsón, E., Royo, S., \& Ratkai, M. (2015). Citizens' engagement on local governments facebook sites. An empirical analysis: The impact of different media and content types in Western Europe. Government Information Quarterly, 32(1), 52-62.

Bonsón, E., Royo, S., \& Ratkai, M. (2017). Facebook practices in Western European municipalities: An empirical analysis of activity and citizens' engagement. Administration and Society, 49(3), 320-347.

Bonsón, E., Torres, L., Royo, S., \& Flores, F. (2012). Local e-government 2.0: Social media and corporate transparency in municipalities. Government Information Quarterly, 29(2), 123-132.

Carrizales, T. (2008). Functions of E-government: A study of municipal practices. State \& Local Government Review, 40(1), 12-26.

Chalmers, A. (2014). In over their heads: Public consultation, administrative capacity and legislative duration in the European Union. European Union Politics, 15(4), 595-613.

da Cruz, N., Tavares, A., Marques, R., Jorge, S., \& de Sousa, L. (2016). Measuring local government transparency. Public Management Review, 18(6), 866-893.

Dalton, R. (2002). Parties without partisans: Political change in advanced industrial democracies. Oxford; New York: Oxford University Press.

De Ceuninck, K., Reynaert, H., Steyvers, K., \& Valcke, T. (2010). Municipal amalgamations in the Low Countries: Same problems, different solutions. Local Government Studies, 36(6), 803-822.

Djerf-Pierre, M., \& Pierre, J. (2016). Mediatised local government: Social media activity and media strategies among local government officials 1989-2010. Policy and Politics, 44(1), 59-77.

Domínguez, L., Nchez, I., \& Álvarez, I. (2011). Determining factors of e-government development: A worldwide national approach. International Public Management Journal, 14(2), 218-248.

Duggan, M., \& Brenner, J. (2013). The Demographics of Social Media Users-2012. Washington, DC: Pew Research Center's Internet \& American Life Project1-14 2013.

Ellison, N., \& Hardey, M. (2013). Developing political conversations? Information, Communication \& Society, 16(6), 878-898.

Ellison, N., \& Hardey, M. (2014). Social media and local government: Citizenship, consumption and democracy. Local Government Studies, 40(1), 21-40.

Enli, G., \& Skogerbø, E. (2013). Personalised campaigns in party-centered politics: Twitter and Facebook as arenas for political communication. Information, Communication \& Society, 16(5), 757-774.

Foster, C., \& Frieden, J. (2017). Crisis of trust: Socio-economic determinants of Europeans' confidence in government. European Union Politics, 18(4), 511-535.

Fox, R., \& Schuhmann, R. (2014). Gender and local government: A comparison of women and Men City managers. Public Administration Review, 59(3), 231-242.

Gallego-Álvarez, I., Rodríguez-Domínguez, L., \& García-Sánchez, I. (2010). Are determining factors of municipal E-government common to a worldwide municipal view? An intra-country comparison. Government Information Quarterly, 27(4), 423-430.

García, A., \& García-García, J. (2010). Determinants of online reporting of accounting information by Spanish local government authorities. Local Government Studies, 36(5), 679-695.

Grimmelikhuijsen, S. G., \& Feeney, M. K. (2016). Developing and testing an integrative framework for open government adoption in local governments. Public Administration Review, 77(4), 579-590.

Grover, P., Kar, A. K., Dwivedi, Y. K., \& Janssen, M. (2018). Polarization and acculturation in the 2016 US presidential election: Can twitter analytics predict changes in voting preferences? Technological Forecasting and Social Change. https://doi.org/10. 1016/j.techfore. 2018.09.009.

Guillamón, M.-D., Ríos, A.-M., Gesuele, B., \& Metallo, C. (2016). Factors influencing social media use in local governments: The case of Italy and Spain. Government Information Quarterly, 33(3), 460-471.

Hanssen, G. S. (2007). ICT in Norwegian local government - empowering the politicians? Local Government Studies, 33(3), 355-382.

Haro-de-Rosario, A., Sáez-Martín, A., \& Caba-Pérez, M. C. (2018). Using social media to enhance citizen engagement with local government: Twitter or Facebook? New Media \& Society, 20(1), 29-49.
Hofmann, S., Beverungen, D., Räckers, M., \& Becker, J. (2013). What makes local governments' online communications successful? Insights from a multi-method analysis of Facebook. Government Information Quarterly, 30(4), 387-396.

Jalali, C. (2014). For whom the bailout tolls? The implications of the 2013 local elections for the Portuguese party system. South European Society and Politics, 19(2), 235-255.

Kahne, J., \& Bowyer, B. (2018). The political significance of social media activity and social networks. Political Communication, 1-24. https://doi.org/10.1080/10584609. 2018.1426662.

Kapoor, K., Tamilmani, K., Rana, N., Patil, P., Dwivedi, Y., \& Nerur, S. (2018). Advances in social media research: Past, present and future. Information Systems Frontiers, 20(3), 531-558.

Katz, J., \& Halpern, D. (2013). Political and developmental correlates of social media participation in government: A global survey of National Leadership Websites. International Journal of Public Administration, 36(1), 1-15.

Kavanaugh, A. L., Fox, E. A., Sheetz, S. D., Yang, S., Li, L. T., Shoemaker, D. J. et al. Xie, L. (2012). Social media use by government: From the routine to the critical. Government Information Quarterly, 29(4), 480-491.

Kleinhans, R., Van Ham, M., \& Evans-Cowley, J. (2015). Using social media and Mobile technologies to Foster engagement and self-Organization in Participatory Urban Planning and Neighbourhood Governance. Planning Practice and Research, 30(3), 237-247.

Larsson, A., \& Kalsnes, B. (2014). "Of course we are on Facebook": Use and non-use of social media among Swedish and Norwegian politicians. European Journal of Communication, 29(6), 653-667.

Larsson, A., \& Skogerbø, E. (2018). Out with the old, in with the new? Perceptions of social (and other) media by local and regional Norwegian politicians. New Media \& Society, 20(1), 219-236.

Lee, G., \& Kwak, Y. H. (2012). An open government maturity model for social mediabased public engagement. Government Information Quarterly, 29(4), 492-503.

Lilleker, D., \& Koc-Michalska, K. (2017). What drives political participation? Motivations and mobilization in a digital age. Political Communication, 34(1), 21-43.

López, M., Martínez, A., \& Oliva, C. (2011). Transparencia financiera de los municipios españoles. Utilidad y factores relacionados. Auditoría Pública, 55, 109-116.

Martín, A. S., de Rosario, A. H., \& Pérez, M. (2015). Using twitter for dialogic communication: Local government strategies in the European Union. Local Government Studies, 41(3), 421-444.

Mergel, I. (2016). Social media institutionalization in the U.S. federal government. Government Information Quarterly, 33(1), 142-148.

Milio, S. (2007). Can administrative capacity explain differences in regional performances? Evidence from structural funds implementation in southern Italy. Regional Studies, 41(4), 429-442.

Moon, M., \& Norris, D. (2005). Does managerial orientation matter? The adoption of reinventing government and e-government at the municipal level. Information Systems Journal, 15(1), 43-60.

Mossberger, K., Wu, Y., \& Crawford, J. (2013). Connecting citizens and local governments? Social media and interactivity in major U.S. cities. Government Information Quarterly, 30(4), 351-358.

Muñoz, J. (2017). Political trust and multilevel government. In S. Zmerli, \& v.d. Meer (Eds.). Handbook on political trust (pp. 69-88). Cheltenham: Edward Elgar Publishing.

Musso, J., Weare, C., \& Hale, M. (2000). Designing web technologies for Local Governance Reform: Good management or good democracy? Political Communication, 17(1), 1-19.

Norris, D. F., \& Reddick, C. (2013). Local E-government in the United States: Transformation or incremental change? Public Administration Review, 73(1), 165-175.

Norris, P. (2003). Preaching to the converted?: Pluralism, participation and party websites. Party Politics, 9(1), 21-45.

OECD (2008). OECD territorial reviews OECD territorial reviews: Portugal 2008. OECD Publishing.

Oliveira, G., \& Welch, E. (2013). Social media use in local government: Linkage of technology, task, and organizational context. Government Information Quarterly, 30(4), 397-405.

Omar, K., Stockdale, R., \& Scheepers, H. (2014). Social media use in local government: An Australian perspective. International Journal of Public Administration, 37(10), $666-675$.

Reddick, C. (2005). Citizen interaction with e-government: From the streets to servers? Government Information Quarterly, 22(1), 38-57.

Reddick, C., \& Norris, D. (2013). Social media adoption at the American grass roots: Web 2.0 or 1.5? Government Information Quarterly, 30(4), 498-507.

Shiau, W.-L., Dwivedi, Y., \& Lai, H.-H. (2018). Examining the core knowledge on Facebook. International Journal of Information Management, 43, 52-63.

Song, C., \& Lee, J. (2016). Citizens use of social media in Government, perceived transparency, and Trust in Government. Public Performance and Management Review, 39(2), $430-453$.

Tavares, A., \& Carr, J. (2013). So close, yet so far away? The effects of city size, density and growth on local civic participation. Journal of Urban Affairs, 35(3), 283-302.

Tavares, A., \& da Cruz, N. (2017). Explaining the transparency of local government websites through a political market framework. Government Information Quarterly, 1-13. https://doi.org/10.1016/j.giq.2017.08.005.

Tavares, A., \& Rodrigues, M. (2013). The supply of political and administrative instruments of participation: An empirical analysis of local government choices. Revista del CLAD Reforma y Democracia, 55, 141-172.

Tolbert, C. J., Mossberger, K., \& McNeal, R. (2008). Institutions, policy innovation, and E government in the American states. Public Administration Review, 68(3), 549-563.

Torcal, M. (2014). The decline of political Trust in Spain and Portugal: Economic performance or political responsiveness? American Behavioral Scientist, 58(12), 1542-1567. 
Vaccari, C. (2017). Online mobilization in comparative perspective: Digital appeals and political engagement in Germany, Italy, and the United Kingdom. Political Communication, 34(1), 69-88.

Wang, S., \& Feeney, M. K. (2016). Determinants of information and communication technology adoption in municipalities. The American Review of Public Administration, 46(3), 292-313.

Warren, A., Sulaiman, A., \& Jaafar, N. (2014). Social media effects on fostering online civic engagement and building citizen trust and trust in institutions. Government Information Quarterly, 31(2), 291-301.

Patrícia Silva (patriciasilva@ua.pt) holds a PhD in Political Sciences with a thesis researching party patronage and party government in the Portuguese context. She is a researcher at the Governance, Competitiveness and Public Policies Research Centre of the University of Aveiro, and was granted a Scientific Employment Stimulus Contract, by the Foundation for Science and Technology (grant number CEECIND/04550/2017). Her main research interests are political parties, the politicization of recruitment of appointed elites, territorial governance and local public sector reform. Her research has been published in international journals - with the most recent articles published in Public Administration and the International Review of Administrative Sciences - and chapters of books in national and international publishers.

Antonio F. Tavares (atavares@eeg.uminho.pt) holds a Ph.D. in Public Administration from Florida State University. He is Associate Professor of the School of Economics and Management and member of the Political Science Research Center at the University of Minho, Portugal. He is also Adjunct Associate Professor at the United Nations University Operating Unit on Policy-Driven Electronic Governance (UNU-EGOV) in Guimarães, Portugal. He is co-editor of the Urban Affairs Review. His main research interests focus on the fields of local government and urban politics, particularly on public service delivery, territorial reforms and regional governance, and political participation. His recent publications include articles in Government Information Quarterly, Policy Studies Journal,
Public Management Review, Public Choice, and Local Government Studies.

Tiago Silva (tiago.silva@unu.edu) is currently an academic fellow at the UNU-EGOV. His main research interests are political communication, media framing, traditional media coverage of politics and the use of new technologies, particularly the Internet and social media, in political campaigns. In its most recent research project, Tiago has been analysing the use of social media by local governments. He holds a PhD in Political and Social Sciences from the European University Institute. He also has a bachelor degree in Public Administration and a Master in Political Science, both from University of Aveiro.

Mariana Lameiras (lameiras@unu.edu) is a Postdoctoral Researcher at the United Nations University Operating Unit on Policy-Driven Electronic Governance (UNU-EGOV) and collaborates with the Communication and Society Research Centre (CSRC) of the University of Minho (Braga-Portugal) in the field of Political Economy of Communication and Communication Policy, with particular interest in governance and media regulation. Her research areas are e-Government, e-Government monitoring and assessment, eParticipation and Digital Media.

She is affiliated to two groups of the Portuguese Association of Communication Sciences (SOPCOM): Young Scholars and Economy and Politics of Communication. She also belongs to the International Federation for Information Processing, Working Group 8.5 (http://faculty.washington.edu/jscholl/ifip.working.group.8.5/website/\#/Home) and to the ICEGOV Community, collaborating with the organization of the ICEGOV Series - International Conference on Theory and Practice of Electronic Governance (http:// www.icegov.org/). She is national correspondent of the European Audiovisual Observatory collaborator (EAO) and the Institute for Information Law (University of Amsterdam), developing collective studies and writing articles on a permanent basis for IRIS - Legal Observations of the EAO and Merlin database. 